\title{
ENCUENTRO DE COMUNICACIÓN MIRADAS MÚLTIPLES
}

Por Paola Papa
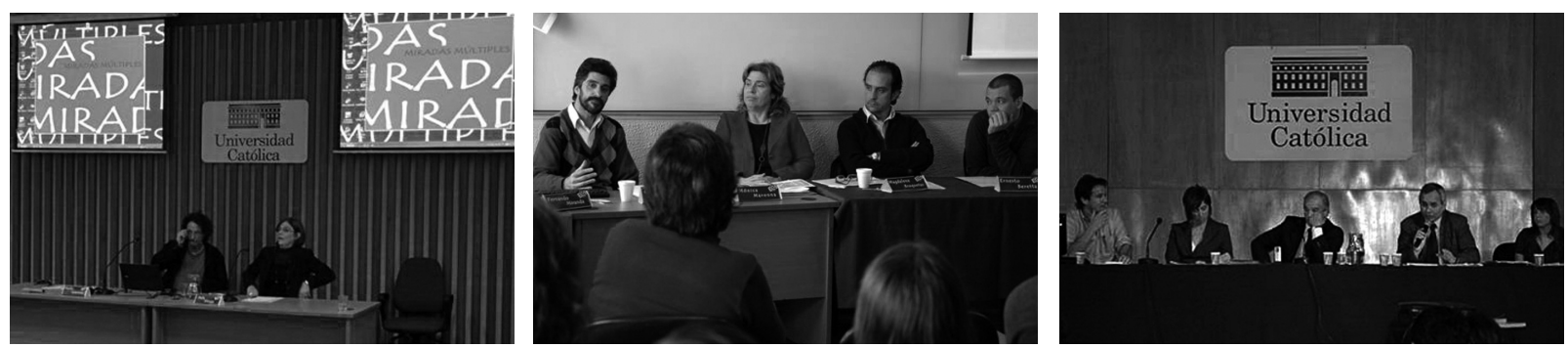

El Encuentro de Comunicación Miradas Múltiples se realizó el 14 y 15 de setiembre en la Universidad Católica del Uruguay. El desafío fue generar un espacio para hacer visible la reflexión sobre la disciplina y la licenciatura. Participaron docentes, investigadores, profesionales y estudiantes, quienes expusieron miradas renovadas sobre el campo de la comunicación. El Encuentro se estructuró en cinco ejes temáticos, con conferencias, charlas y mesas de ponencia y de trabajo:

1) Tecnologías y nuevas tendencias en la producción y el consumo mediático. El Dr. Guillermo Orozco, investigador mexicano y docente de la Maestría en Comunicación y Cultura de nuestra universidad, presentó la investigación del Observatorio Iberoamericano de la Ficción Televisiva (OBITEL). Esta red de monitoreo comparativo, que nuclea a investigadores de ocho universidades, realiza análisis sistemáticos de la producción, la transmisión y la recepción de ficción para televisión, para promover la producción audiovisual, así como el desarrollo de políticas públicas. La responsable del capítulo uruguayo fue la Mag. Rosario Sánchez, de la Universidad Católica. Además, se realizaron las mesas "Nuevas Tendencias en el consumo mediático" e "Internet: un mundo de oportunidades en Uruguay. Creatividad, producción y negocios online”.

2) Problemas actuales en la conservación de archivos fotográficos, sonoros y audiovisuales. La conferencia y el taller sobre "Análisis conceptual y clasificación de la información audiovisual" fueron conducidos por el Prof. Jorge Gagliardi, director del Núcleo Audiovisual de Buenos Aires. La mesa de ponencia sobre "Historia de los medios y prácticas culturales" estuvo a cargo del Programa de investigación Comunicación y Cultura. Se realizaron, además, dos mesas de trabajo: "Restau- ración digital de imágenes”, que contó con la participación del Dr. Marcelo Bertalmío, de la Universidad Pompeu Fabra de Barcelona, y "Los archivos como insumo de nuevas realizaciones", con la presencia del montajista argentino Patricio Coll.

3) Desafíos de la enseñanza y aprendizaje en comunicación. En este eje temático se realizaron dos mesas de trabajo: "Experiencias docentes en la enseñanza de la disciplina" y "Usos educativos de las TICs".

4) Responsabilidades éticas de los comunicadores sociales y los medios. Docentes y profesionales se acercaron para debatir sobre su práctica profesional y los dilemas éticos que enfrentan, abordando temas de responsabilidad social y ética con periodistas de todos los medios. Se abordó desde dos mesas de trabajo: “Comunicación comunitaria” y "La participación del lector en la prensa”, donde se presentaron diversas experiencias y propuestas.

5) Actualización del marco legal en comunicación. Expertos presentaron las regulaciones necesarias para el desarrollo de la profesión, como "La propiedad intelectual de terceros en el trabajo del comunicador", "Actualización en materia de libertad de expresión" y la posibilidad de una "Ley de cine en Uruguay”.

Otras conferencias y charlas tuvieron lugar en el Encuentro, además de las muestras de productos realizados por estudiantes, producciones curriculares y extracurriculares, de nuestra universidad y de otras universidades, que sumaron a las miradas desde lo académico profesional. El encuentro se constituyó en un buen espacio para pensar en la formación y reflexionar sobre el ejercicio profesional.:-
Paola Papa:: (Montevideo). Es coordinadora de la Licenciatura en

Comunicación Social de la Universidad Católica del Uruguay. Además de una extensa trayectoria en este programa académico, ha trabajado en medios de comunicación, particularmente en radio.

Fotos cedidas por la organización del evento 